\title{
HLA-C and HIV-1: friends or foes?
}

\author{
Donato Zipeto ${ }^{1}$ and Alberto Beretta ${ }^{2^{*}}$
}

\begin{abstract}
The major histocompatibility complex class I protein HLA-C plays a crucial role as a molecule capable of sending inhibitory signals to both natural killer (NK) cells and cytotoxic T lymphocytes $(C T L)$ via binding to killer cell Ig-like receptors (KIR). Recently HLA-C has been recognized as a key molecule in the immune control of HIV-1. Expression of HLA-C is modulated by a microRNA binding site. HLA-C alleles that bear substitutions in the microRNA binding site are more expressed at the cell surface and associated with the control of HIV-1 viral load, suggesting a role of HLA-C in the presentation of antigenic peptides to CTLS. This review highlights the role of HLA-C in association with HIV-1 viral load, but also addresses the contradiction of the association between high cell surface expression of an inhibitory molecule and strong cell-mediated immunity. To explore additional mechanisms of control of HIV-1 replication by HLA-C, we address specific features of the molecule, like its tendency to be expressed as open conformer upon cell activation, which endows it with a unique capacity to associate with other cell surface molecules as well as with HIV-1 proteins.
\end{abstract}

Keywords: MHC class I, HLA-C, Open conformers, HIV-1, CTL, NK cells, KIR, $\beta_{2}$ microglobulin

\section{Review}

Introduction

The major histocompatibility complex (MHC) class I loci are the most polymorphic mammalian genes. The human MHC class I system includes 3 main loci, namely HLA-A, $-\mathrm{B}$ and $-\mathrm{C}$, and some non-classical HLA genes such as $-\mathrm{E}$, $-\mathrm{F}$ and $-\mathrm{G}$. The HLA-B locus is the most polymorphic, with 1795 proteins known, followed by HLA-A with 1290, and HLA-C with 946 (http://www.ebi.ac.uk/imgt/hla/stats. $\mathrm{html}$ ). Among the classical MHC class I genes, HLA-C has the least allelic variability [1].

MHC class I molecules consist of a $45 \mathrm{kDa}$ heavy, $\alpha$-chain (divided in 3 subdomains, $\alpha 1, \alpha 2$ and $\alpha 3$ ) non-covalently associated with a light $\beta$ chain, the $\beta_{2}$-microglobulin $\left(\beta_{2} \mathrm{~m}\right)$, and a short $(8-11 \mathrm{mer})$ peptide antigen derived from the degradation of intracellular proteins [2]. MHC class I assembly occurs in the lumen of the endoplasmic reticulum (ER) with the help of molecular chaperons like calreticulin, ERp57 and tapasin [3]. After leaving the ER the trimeric complexes egress through the Golgi complex to the plasma membrane. At the plasma membrane they can interact with two main types of ligands: the $\mathrm{T}$ cell receptor (TCR) of CD8 $+\mathrm{T}$ cells and natural killer cells $(\mathrm{NK})$ receptors including

\footnotetext{
* Correspondence: alberto@gmail.com

${ }^{2}$ Infectious Diseases Department IRCCS Ospedale San Raffaele Via Stamira d'Ancona 20, 20127 Milan Italy

Full list of author information is available at the end of the article
}

immunoglobulin receptors (KIRs), leukocyte immunoglobulin receptors (LILRs) [4,5] and NKG2A/C [6].

It is generally agreed that HLA-C is surface-expressed at levels much lower (sometimes said to be ten-fold lower) than HLA-A and HLA-B [7] despite similar levels of transcription and translation [8]. Several authors provided evidence for transcriptional, post-transcriptional, as well as post-translational impairments (reviewed in [9]). Due to such considerable redundancy in the mechanisms accounting for low HLA-C expression, different HLA-C alleles may be affected to various degrees in different cell types or biological conditions. A post-translational biosynthetic bottleneck appears nevertheless to be common, in that it causes the backward accumulation of chaperone-associated and deeply unfolded HLA-C heavy chain conformers of all the 8 serologically defined $\left(\mathrm{Cw}^{*} 01\right.$ through $\left.\mathrm{Cw}^{*} 08\right)$ alleles. This bottleneck is due to the HLA-C-specific KYRV heavy chain motif, initially noted by Zemmour and Parham [10] and subsequently proposed to provide HLA-C with reduced binding groove plasticity and selective peptide-assembly properties [9].

The mature trimeric HLA-C complexes expressed at the cell surface tend to dissociate and generate a pool of heavy chains, lacking peptide and $\beta_{2} \mathrm{~m}$. The surface expression of free HLA-C heavy chains, also called "open conformers", is a hallmark of activated and transformed cells, including lymphocytes $[11,12]$. The expression of HLA-C open 
conformers is also upregulated by treatment with IFN- $\gamma$ in human trophoblasts [13] and in other human cells belonging to a variety of lineages [12].

An additional selective feature of HLA-C lies in its cytoplasmic domain containing a di-hydrophobic internalization signal (DXSLI), which is specifically inhibited upon macrophage differentiation, allowing high HLA-C surface expression on macrophages [14]. The specific induction of HLA-C expression on differentiated macrophages may play a role in the down-modulation of the normal $\mathrm{CD} 8+\mathrm{T}$ cell response to specifically limit the lysis of antigen-presenting cells (APC) that cross-present the antigen [14]. Thus, it appears that complex mechanisms tightly regulate the expression of HLA-C, maintaining significant intracellular levels and limiting surface expression on resting cells, but also rapidly mobilizing the intracellular pool to allow surface expression after cell activation or differentiation.

HLA-C presents antigen to cytotoxic T lymphocytes less efficiently than either HLA-A or -B [15]. In contrast, HLA-C is an extremely good ligand for KIR receptors on NK cells and protects target cells from lysis mediated by NK cells [16]. The HLA-C-mediated protection is relevant to many viral infections, including $\mathrm{HCV}[17,18]$ and HIV-1 [19-24]. Inhibitory HLA-C/KIR interactions influence the outcome of HCV infection and confer protection [17]. Several lines of evidence highlight the importance of NK cells in the setting of HIV-1 infection [19-24]. Furthermore, HIV-1 has developed a sophisticated pathway to modulate, to its own advantage, the surface expression of MHC class I molecules. The suppression of HLA-A and -B, but not $-C$, results in escape of immune recognition of HLA-A and $-B$ peptides by CTL. At the same time an efficient NK inhibitory signal at the surface is maintained [25-31], pointing to a selective advantage for HIV-1, which results in maintenance of a sufficient level of cell-surface HLA-C expression.

Further complexity has been added by the discovery of a post-transcriptional mechanism of HLA-C expression control [32]. Specifically, such control depends on the expression of an intact microRNA binding site in the 3' UTR of the HLA-C gene. Strong genetic association between HLA-C alleles with a mutated microRNA binding site, higher protein expression, and control of HIV-1 replication was reported. These findings are in contradiction with the view of HLA-C as an inhibitory molecule and call for a general reappraisal of the role of HLA-C in HIV-1 infection.

\section{MHC class I genes and control of HIV-1}

Experimental evidence shows that $\mathrm{CD} 8+\mathrm{T}$ cells play a central role in controlling HIV-1 viremia during primary infection as well as in the long-term suppression of viral replication [33]. The correlation between expression of specific MHC class I alleles and HIV-1 control strongly supports this idea. Early studies performed in the late 1980 's on small cohorts of AIDS patients reported an increased frequency of C*04 and B*35 in HIV-1-infected patients compared to non-infected controls [34], an elevated $C * 04$ frequency in patients with Kaposi's sarcoma and of $C^{*} 07$ in patients with opportunistic infections [35]. Subsequent studies reported an increased prevalence of C*07 in HIV-1 positive individuals [36]. A larger study published in 1999 established the association of $C^{*} 04$ and $B * 35$ with rapid development of AIDS-defining conditions in Caucasians [37], and also showed that maximum homozygosity at the HLA-B locus was more detrimental than homozygosity at either HLA-A or -C. A follow up study from the same group showed that peptide presentation properties of particular $B * 35$ subtypes explain much of this association [38]. The dominance of HLA-B in the control of HIV-1 infection is supported by several studies which associated HLA-B*57, B*5801 and B*27 with slower disease progression rates (time to AIDS) and strong virologic (viral load) and immunologic control (CD4 count) [3948], while $B * 35, B * 5802$ and $B * 18$ were associated with ineffective control of viral replication and rapid progression to AIDS $[37,43,44,47,49,50]$. In addition, a significantly greater number of CD8+ $\mathrm{T}$ cell responses are HLA-B restricted, compared to HLA-A and -C. Variation in viral set-point, absolute CD4 count, and rate of disease progression are strongly associated with particular HLA-B, but not $-\mathrm{A}$ or $-\mathrm{C}$ alleles [43]. Recently, a study on blood donors in China who were contaminated by a narrow source blood-born virus showed that HLA-B exerts a greater selection pressure on HIV evolution than other HLA molecules [51].

On the other hand, there is evidence of interdependent protective effects of the HLA-C*0401-B*8101, HLAC"1203-B*3910 and HLA-A*7401-B*5703 haplotypes that cannot be explained solely by linkage to a protective HLA$B$ allele. Therefore, although individual HLA alleles, particularly HLA-B, can have a strong impact, HIV-1 control is likely to be influenced by the additive effect of some or all the other HLA alleles present [45]. Other HLA alleles combinations like HLA-B*5701-C*0602, HLA-B*2705-C*0102, or HLA-B*3801-C*1203 also exert a strong effect on nonprogression, reinforcing the hypothesis of an additive effect of protective HLA alleles [48,52]. More recently, a study on HIV-infected children identified HLA-C*02 as a protective allele while confirming a strong protective effect of the $B * 27$ allele [53].

HLA-C drives viral evolution through the selection of CTL escape mutants. A recent study used three phylogenetic correction methods across a full HIV-1 subtype $\mathrm{C}$ proteome and identified amino acids conferring either susceptibility or resistance to CTLs [54]. Three hundred and ten groups of HLA-amino acid associations were 
identified, each predicted to be related to single epitope/ HLA combinations (immunological set). The immunological set with the most individual associations was found within Nef and included a B*44-restricted epitope (molecules of the Bw4 subfamily of HLA-B alleles). The next largest immunological sets were in Nef, Tat and Pol and included six associations involving a C*0404restricted epitope as well as two $B * 42$-restricted epitopes [55]. CTL escape mutants were also identified in a $\mathrm{CW}^{*} 12$ restricted pol epitope [54].

Recently, genome-wide association studies (GWAS) were applied to the study of genetic control of HIV-1. These studies do not rely on candidate gene selection and have the potential to identify new genomic regions and pathways affecting human diseases [56]. The first study identified genetic polymorphisms associated with viral load during the asymptomatic phase of infection, as well as time to HIV-1 disease progression [57]. Two independently acting groups of polymorphisms associated with HLA loci B and C were identified explaining $9.6 \%$ and $6.5 \%$, respectively, of the total variation in viral set point. The first polymorphism, located in the HLA complex P5 (HCP5), is in high linkage disequilibrium with the $\mathrm{B}^{*} 5701$ allele [58]. The second polymorphism $(\mathrm{C} / \mathrm{T})$ is located in the $5^{\prime}$ region of the HLA-C gene $35 \mathrm{~kb}$ away from transcription initiation. This single nucleotide polymorphism (SNP) associates with differences in HLA-C expression levels. The protective allele (C SNP) leads to lower viral load and is associated with higher expression of HLA-C [57].

A second GWAS (The International HIV Controllers Study) [59] conducted in a multiethnic cohort of HIV-1 controllers and progressors analyzed the effects of individual amino acids within the classical HLA proteins. In the group of individuals of European ancestry, 4 independent markers of association were identified, which included the $-35 \mathrm{~kb}$ and the HCP5 SNPs previously identified [57]. In addition, B*57.01, B*27:05, B*14/C*08:02, B*52, and $A * 25$ were identified as protective alleles and $B * 35$ and $C * 07$ as risk alleles. The study also evaluated the impact of specific amino acid positions within the HLA molecules and identified six residues as independent markers associated with control of HIV-1: $\mathrm{Arg}^{97}, \mathrm{Cys}^{67}$, Gly ${ }^{62}$, and $\mathrm{Glu}^{63}$, all in HLA-B; $\mathrm{Ser}^{77}$ in HLA-A and Met ${ }^{304}$ in HLA-C. Collectively these residues explained $20 \%$ of the variance. Interestingly, all these residues, with the exception of $\mathrm{Met}^{304}$ of HLA-C, are in the peptide-binding groove. Position 304 is a biallelic variant (Val/Met) located in the transmembrane domain of HLA-C, which is in moderate linkage disequilibrium with the -35 SNP associated with HLA-C expression level. Therefore mechanisms other than peptide selection by polymorphic HLA-C residues may underlie the association between HLA-C expression and HIV-1 control [59]. Collectively, the data generated by the GWAS confirmed the dominance of HLA-B in host control of HIV-1, but also revealed a novel mechanism of control related to HLA-C expression.

The association between the -35 SNP and HIV-1 viral load has been questioned in a work by Corrah and colleagues who showed that differences in HLA-C expression across -35 SNP genotypes can be attributed primarily to the very low expression of a single allelic product, HLA$\mathrm{Cw}^{*} 07$ [60].

Some individuals with the reported protective -35CC SNP genotype exhibit high viral loads. HIV-1 variants isolated in these patients counteract HLA-C-mediated immune control of HIV-1 by enhancing Nef mediated viral infectivity. This was not due to an acquired ability of Nef to down-modulate HLA-C or in a more efficient ability to down-modulate HLA-A and $-\mathrm{B}$, but rather to an indirect mechanism interfering with T-cells function and MHC-II antigen presentation [61].

\section{Post-transcriptional regulation of HLA-C expression}

Recently, Kulkarni et al. [32] discovered that the $-35 \mathrm{~kb}$ SNP is not the causal variant for differential HLA-C expression, but rather marks another polymorphism in the 3' UTR region of HLA-C that directly controls the levels of HLA-C [32]. The 3' UTR variant affects binding of a microRNA (miR-148a) to its target site resulting in relatively low surface expression of HLA-C alleles that bind this miRNA ("inhibited alleles") and high expression of HLA-C alleles that escape the miRNA control ("escape alleles"). HLA-C alleles, such as C*01, C*03, C*04, C07*, $C^{*} 14$ and $C^{*} 17$, contain an intact miR-148 binding site, and their expression is down-regulated ("inhibited alleles"). On the contrary, C*02, C*05, C*06, C*08, C*12, $C^{*} 15$ and $C * 16$, containing a disrupted binding site, are highly expressed (escape alleles). These findings offer a rational explanation of different HLA-C expression levels initially reported to be associated with the $-35 \mathrm{~kb}$ SNP and are also consistent with previous genetic association studies which identified $C^{*} 04$ and $C^{*} 07$ (inhibited alleles) as risk alleles [34-36] and $C^{*} 02$ and $C^{* * 12}$ [52] (escape alleles) as protective alleles [53]. A subsequent study showed that the common ancestor of all extant HLA$\mathrm{C}$ alleles was suppressed by $\mathrm{miR}-148 \mathrm{a}$ and that substitutions that prevent miR-148a binding arose by a recombination event between an ancestral HLA-C allele and an HLA-B allele of the HLA-B*07-like lineage. This resulted in conversion of the $3^{\prime}$ UTR of the original HLA-C allele by the paralogous HLA-B region. This event is likely to have occurred 3 to 5 million years ago, after the split of humans from great apes, resulting in HLA-C variants that escape control by miR-148 [62]. The frequency of the escape alleles in worldwide populations is high, constituting an estimated $32.8 \%$ of HLA-C alleles. In addition, many polymorphisms and functional motifs specific for HLA- 
$\mathrm{C}$ alleles are present in both escape and inhibited lineages indicating that selection has been instrumental in the diversification of the escape lineage [62].

On the other hand, the inhibited alleles may also provide benefit, since they have been maintained in evolution, and they have been identified as restricting elements for HIVspecific CTL clones [63-68]. Notably, with the exception of one CTL clone restricted to HLA-C*15 (an escape allele) [63], all other clones are restricted to inhibited HLA-C alleles like HLA-C*01 [69], -C*03 [63,66], -C*04 $[64,65,67,68]$ and $-C^{*} 07$ [63]. Furthermore, $\mathrm{Cw}^{*} 07$ restricted CTLs were detected in non-progressor patients [70], and a $\mathrm{Cw}^{*} 04$ restricted epitope was associated with the generation of CTLs escape mutants [55].

\section{HLA-C and NK cells}

NK cells express receptors (KIR) which interact with the $\alpha 1$ domain of MHC class I molecules resulting in inhibition or activation of cytolysis [71]. HLA-C alleles are the main inhibitory ligands for KIRs, protecting target cells from lysis mediated by NK cells $[16,72]$. HLA-C/KIR interactions have been shown to play a key role in placentation [73].

KIR distinguishes HLA-C alleles into two groups, namely $\mathrm{C} 1$ and $\mathrm{C} 2$, depending on a dimorphism present in the $\alpha 1$ domain [74,75]. In particular, KIR2DL2 and 3 bind with greater affinity to HLA-C group 1, while KIR2DL1 bind to HLA-C group 2 [76]. Homozygosity for HLA-C1 alleles and KIR2DL3 is associated with resolution of $\mathrm{HCV}$ infection as compared to homozygosity or heterozygosity for HLA-C2 [17]. In the case of HIV-1, resistance to infection has been associated with the presence of inhibitory KIR in the absence of their HLA-C ligands [20] The activating receptor KIR2DS4 was associated with high viral load and accelerated transmission although this effect was independent of the putative ligand HLA-Cw*04 [22]. HLA-C1 alleles were also associated with an increased magnitude of NK cell response in HIV-1 infected subjects [24]. The KIR2DL2-HLA-C1 compound was also shown to drive viral evolution in vivo since KIR2DL2-associated HIV-1 sequence polymorphisms were shown to enhance the binding of inhibitory KIRs to HIV-1 infected CD4+ T cells and to reduce anti-viral activity of KIR-positive NK cells thereby enabling HIV-1 to escape the potential protective role of KIR [77].

Another KIR/HLA compound genotype relevant to HIV1 control is KIR3DL1 and KIR3DS1, which encode receptors for molecules of the Bw4 subfamily of HLA-B alleles. The activating allele, KIR3DS1, when present in combination with Bw4, is associated with lower viral load, slower decline of CD4+ T cells and delayed progression to AIDS [21]. KIR3DS1 is also associated with strong inhibition of viral replication [19]. The importance of the KIR3DL1/ KIR3DS1 locus in control of viral set point was recently confirmed by a GWAS that assessed the copy number variant of KIR3DL1/KIR3DS1. The study showed that an increase in KIR3DS1 count associates with a lower viral set point if its putative ligand is present, as does an increase in KIR3DL1 count in the presence of KIR3DS1 and the appropriate ligands for both receptors, suggesting that the relative amounts of activator and inhibitory KIR regulate the expansion of antiviral NK cells [23].

It should be considered, however, that inhibition by HLA$B$ allotypes is less common compared to inhibition by HLA-C since it has only been shown for the Bw4 subfamily. In contrast, since nearly all KIR allotypes worldwide contain KIR2DL1 along with either KIR2DL3 or KIR2DL2, HLA-C molecules almost always inhibit a subset of each individual's NK cell population.

Although generally considered NK cell receptors, KIR are also expressed by a large fraction of effector memory T cells, which, like NK cells, are immediate effector cells that are cytotoxic and produce IFN- $\gamma$ (reviewed in van Bergen and Koning [78]). On cytotoxic T cells, KIRs modulate signals driven by the $\mathrm{T}$-cell receptor and inhibit cytokine secretion, degranulation, and proliferation. In HIV-1 infection, KIR expression on cytotoxic T cells is progressively upregulated, and this correlates with the level of viral replication [79]. Interestingly, the upregulation of KIR occurs in individuals who do or do not express the respective KIR ligands, suggesting a possible ligand-independent blockade of TCR activation [79].

\section{Virion HLA-C molecules and HIV-1 infectivity}

During the process of budding from the cell membrane, MHC class I and II molecules are incorporated into the HIV-1 envelope together with other cell proteins [80-85]. HIV-1 viral particles have been shown to carry more MHC molecules than Env trimers [86-88]. The process of host cell protein incorporation is neither random nor dependent on the amount of protein on the cell membrane, since some highly expressed proteins such as CD4, CD45, CCR3, CCR5 or CXCR4, are not incorporated. The preferential incorporation in the budding envelopes suggests a role in the pathogenesis of HIV-1 [80]. For instance, virion-associated MHC class II molecules have been shown to confer higher viral infectivity, possibly enhancing CD4 binding [89,90].

There is evidence that virion HLA-C molecules play a role in HIV-1 infectivity. Fusion between the viral envelope and the cell membrane is increased by HLA-C [91]. This effect is not due to binding to a specific cellular ligand, since the natural CD8 MHC class I ligand is not expressed on cells susceptible to HIV-1 infection. Cosma et al. reported that $\mathrm{MHC}$ class I negative cells are nonpermissive for replication of primary HIV-1 isolates, and transfection of HLA-C restores their permissivity. This effect of HLA-C is also evident, but to a lesser extent, with $\mathrm{T}$ cells line-adapted viruses [92]. HLA-C molecules associate non-covalently with the HIV-1 envelope 
glycoprotein gp120 [92]. Gp120 purified from HLA-C positive virions displays conformational changes, which include an enhanced exposition of epitopes normally available upon $\mathrm{CD} 4$ binding. In addition, virus incorporation of HLA-C reduces the susceptibility to neutralizing antibodies [92].

The effect of HLA-C on HIV-1 infectivity was further studied by Matucci et al. [93] who showed that fusion efficiency is reduced in HLA-C silenced cells and that pseudoviruses produced in HLA-C silenced cells are significantly less infectious compared to those produced in non-silenced cells. The study also confirmed the association between HLA-C and gp120 demonstrating that HLA-C molecules are detectable, together with gp120, CD4 and CCR5 within molecular complexes which form on cells during the process of HIV-induced cell-to-cell fusion (fusion complexes).

These studies addressed the association between gp120 and HLA-C using an HLA-C specific monoclonal antibody, L31 [11], which was originally derived from a mouse immunized with purified HIV-1 virions [94] and later shown to bind all HLA-C and a few rare HLA-B open conformers [94,95]. L31 binding to HLA-C is strictly dependent on the presence of aromatic amino acids (Phe or Tyr, present in HLA-C and certain HLA-B alleles) at position 67 of the locus-specific motif on the $\alpha 1$ helix [11], which is buried deep in the binding groove [96]. The gp120/ HLA-C association appears, therefore, to selectively involve the open conformers of HLA-C. Enhancement of HIV-1 infectivity was observed in cell lines transfected with three inhibited HLA-C alleles (C*03, "04 and $* 07)$ and one escape allele $(C * 12)$ expressed in heterozygosity with $\mathrm{C}^{* 07}$ (see Table 1 ).
In T lymphocytes, HIV-1 assembly, budding, and release occur at the plasma membrane, while in macrophages they occur in intracellular compartments such as the late endosomes [97]. This process is coordinated by the viral protein Gag [98]. MHC class II molecules, which are expressed on macrophages and activated $\mathrm{T}$ cells, relocate Gag to late endosomes and substantially decrease viral production and release from the cell surface [97]. HLA-C molecules, like other MHC class I molecules, are mobilized from late endosomes to the cell surface [99] and may therefore play a similar role, acting as chaperones of the viral envelope proteins and participating to the process of virus assembly and budding.

MHC class I open conformers have been shown to be able to cis-associate both with themselves and with a variety of membrane receptors, including $\mathrm{CD} 3, \mathrm{CD} 8 \alpha \beta$, CD25, Ly49A and IL-15R $\alpha$ [100] and tend to maintain an ordered and non-denatured structure. HLA-C binds weakly to $\beta_{2} \mathrm{~m}$ and has the longest reported half-life compared to other free MHC class I heavy chains [101]. This property may confer to HLA-C open conformers a selective propensity for associating with viral proteins.

\section{Conclusions}

HLA-C can influence the outcome of HIV-1 infection in at least three distinct and potentially opposite ways: (a) promoting effective CTL recognition and lysis of HIV-infected cells, (b) inhibiting NK cell recognition and lysis of infected cells, and (c) favoring the formation of infective virions via its association with the envelope protein. The extent to which genetic polymorphisms associated with control of HLA$\mathrm{C}$ expression levels influence these three properties

Table 1 principal characteristics of the main HLA-C variants

\begin{tabular}{|c|c|c|c|c|c|c|c|c|}
\hline HLA-C allele & $\begin{array}{l}\text { miR418a site/expression } \\
{[32,34-36,52,53,59]}\end{array}$ & $\begin{array}{l}-35 \mathbf{k b} \\
\text { SNP [32] }\end{array}$ & $\begin{array}{l}\text { Val/Met } \\
304[57,59]\end{array}$ & $\begin{array}{l}\text { KIR group } \\
\text { type }[74,75]\end{array}$ & $\begin{array}{l}\mathrm{CTL} \\
\text { restriction }\end{array}$ & $\begin{array}{l}\text { Association } \\
\text { with control }\end{array}$ & $\begin{array}{l}\text { Association with } \\
\text { progression }\end{array}$ & $\begin{array}{l}\text { Increase of HIV-1 } \\
\text { infectivity }[92,93]\end{array}$ \\
\hline 01.02 & Intact/Low & C & Val* & $\mathrm{C} 1$ & {$[69]$} & & & NT \\
\hline 02.02 & Deleted/High & C & Val* & $C 2$ & & [53] & & NT \\
\hline $03.03, .04$ & Intact/Low & $\mathrm{T}$ & Val* & $\mathrm{C} 1$ & {$[63,66]$} & & & Yes \\
\hline 04.01 & Intact/Low & $\mathrm{T}$ & Val* $^{*}$ & $C 2$ & [63-68] & & {$[34,37]$} & Yes \\
\hline 05.01 & Deleted/High & C & Met*Nal* $^{*}$ & $\mathrm{C} 2$ & & & & NT \\
\hline 06.02 & Deleted/High & C & $\operatorname{Met}^{*} \mathrm{Nal}^{*}$ & $\mathrm{C} 2$ & & & & NT \\
\hline $07.01, .02, .04$ & Intact/Low & $\mathrm{T}$ & Val & $\mathrm{C} 1$ & {$[63,70]$} & & {$[36]$} & Yes \\
\hline $08.01, .02, .04$ & Deleted/High & $C$ & Met $^{*}$ Nal $^{*}$ & $\mathrm{C} 1$ & & & & $\mathrm{NT}$ \\
\hline $12.02, .03$ & Deleted/High & $C$ & Met* Nal* $^{*}$ & $\mathrm{C} 1^{*}$ & {$[54]$} & {$[54]$} & & Yes ?** \\
\hline 14.02 & Intact/Low & C & Val* $^{*}$ & $\mathrm{C} 1^{*}$ & & & & $\mathrm{NT}$ \\
\hline $15.02, .05, .06$ & Deleted/High & $\mathrm{T}$ & Met*Nal* $^{*}$ & $C 2^{*}$ & {$[63]$} & & & NT \\
\hline $16.01, .02, .04$ & Deleted/High & $\mathrm{T}$ & Val* & $\mathrm{C} 1^{*}$ & & & & NT \\
\hline 17.01 & Intact/Low & $\mathrm{T}$ & Val $^{*}$ & $C 2^{*}$ & & & & NT \\
\hline
\end{tabular}

*: data obtained by sequence alignment analysis.

**: $C^{*} 12 / C^{*} 07$.

NT not tested. 
of the molecule is largely unknown. The strong genetic association between high expression of HLA$\mathrm{C}$ and control of HIV-1 suggests that, at least, in the initial setting of HIV-1 infection, the role of HLA-C in inducing an effective CTL response dominates over other functions of the molecule. However, the role of the escape (highly expressed) HLA-C allotypes in the induction of CTL responses needs further investigation, since only a handful of HLA-C specific CTL clones restricted to escape alleles have been reported so far, while the majority of clones are restricted to inhibited alleles [102] (see Table 1). In addition, no significant associations between HIV-1 control and amino acid positions located in the HLA-C peptide binding pocket were identified by the GWAS, as it would be predicted if selection of antigenic peptides by HLA-C were to play a major role in control [59], by analogy with HLA-B. Thus, if high cell surface expression of HLA-C suggests a more potent induction of cytotoxic $\mathrm{T}$ cell responses, other properties and functions of the escape alleles may contribute to the control of viral replication. The main feature of HLA-C molecules is their poor assembly efficiency, which results in intracellular accumulation as open conformers. Differences in binding affinity to their cognate ligand, $\beta_{2} \mathrm{~m}$, or to alternative ligands may confer to each allelic variant of HLA-C a selective capacity to function as accessory molecule in the process of virus assembly and budding. In addition, preferential association with alternative ligands may affect the pattern of cell surface expression of the alternative isoforms. Accordingly, escape alleles may have a higher affinity with $\beta_{2} \mathrm{~m}$, resulting in higher surface expression of trimeric complexes, but also lower propensity to associate with viral proteins. This property would confer to lymphoid cells of individuals bearing HLA-C escape allotypes a higher sensitivity to CTLs, but also an intrinsically lower capacity to support viral replication. Studies addressing the characterization of the HLA-C molecular isoforms on infected cells expressing escape versus deleted alleles are warranted to gain novel insights into the potential protective or pathogenic properties of HLA-C in HIV-1 infection.

Such studies might help clarifying the apparent contradiction of the association of higher surface expression of an inhibitory molecule with control of HIV-1 and open new perspectives on the role of HLA-C in the modulation of host-virus interactions.

\section{Abbreviations}

APC: Antigen presenting cell; $\beta_{2}$ m: $\beta_{2}$-microglobulin; CTL: Cytotoxic T lymphocyte; ER: Endoplasmic reticulum; GWAS: Genome wide association study; KIR: Killer cell Ig-like receptor; LILR: Leukocyte immunoglobulin receptor; MHC: Major histocompatibility receptor; NK: Natural killer; SNP: Single nucleotide polymorphism; TCR: T cell receptor.

\section{Competing interests}

The authors declare that they have no competing interests.

\section{Acknowledgements}

This study was supported by the Europrise FP6 Network of Excellence, Life Sciences Programme, European Commission, and Italian Ministry of Health, ISS40H92 Grant. We thank Dr. Serena Ziglio for helping in collecting data, Prof. Patrizio Giacomini, from the Regina Elena Cancer Institute in Rome, for helpful discussions and manuscript revision and Dr. Lucy Rasmussen, Stanford University, CA,USA, for critically reviewing, editing and improving the manuscript.

\section{Author details}

${ }^{1}$ Laboratory of Molecular Virology, Department of Life and Reproduction Sciences, Section of Biology and Genetics, University of Verona, Strada le Grazie 8, 37134 Verona, Italy. ${ }^{2}$ Infectious Diseases Department, IRCCS Ospedale San Raffaele, Via Stamira d'Ancona 20, 20127 Milan, Italy.

Received: 2 March 2012 Accepted: 9 May 2012

Published: 9 May 2012

\section{References}

1. Davidson WF, Kress M, Khoury G, Jay G: Comparison of HLA class I gene sequences. Derivation of locus-specific oligonucleotide probes specific for HLA-A, HLA-B, and HLA-C genes. J Biol Chem 1985, 260:13414-13423.

2. Groothuis TA, Griekspoor AC, Neijssen JJ, Herberts CA, Neefjes JJ: MHC class I alleles and their exploration of the antigen-processing machinery. Immunol Rev 2005, 207:60-76.

3. Antoniou AN, Powis SJ, Elliott T: Assembly and export of MHC class I peptide ligands. Curr Opin Immunol 2003, 15:75-81.

4. Cresswell P, Ackerman AL, Giodini A, Peaper DR, Wearsch PA: Mechanisms of MHC class I-restricted antigen processing and cross-presentation. Immunol Rev 2005, 207:145-157.

5. Vivier E, Anfossi N: Inhibitory NK-cell receptors on T cells: witness of the past, actors of the future. Nat Rev Immunol 2004, 4:190-198.

6. Kaiser BK, Pizarro JC, Kerns J, Strong RK: Structural basis for NKG2A/CD94 recognition of HLA-E. Proc Natl Acad Sci U S A 2008, 105:6696-6701.

7. Snary D, Barnstable CJ, Bodmer WF, Crumpton MJ: Molecular structure of human histocompatibility antigens: the HLA-C series. Eur J Immunol 1977, 7:580-585.

8. Neefjes JJ, Ploegh HL: Allele and locus-specific differences in cell surface expression and the association of HLA class I heavy chain with beta 2microglobulin: differential effects of inhibition of glycosylation on class I subunit association. Eur J Immunol 1988, 18:801-810.

9. Sibilio L, Martayan A, Setini A, Lo Monaco E, Tremante E, Butler RH, Giacomini P: A single bottleneck in HLA-C assembly. J Biol Chem 2008, 283:1267-1274.

10. Zemmour J, Parham P: Distinctive polymorphism at the HLA-C locus: implications for the expression of HLA-C. J Exp Med 1992, 176:937-950.

11. Setini A, Beretta A, De Santis C, Meneveri R, Martayan A, Mazzilli MC, Appella E, Siccardi AG, Natali PG, Giacomini P: Distinctive features of the alpha 1-domain alpha helix of HLA-C heavy chains free of beta 2microglobulin. Hum Immunol 1996, 46:69-81.

12. Giacomini P, Beretta A, Nicotra MR, Ciccarelli G, Martayan A, Cerboni C, Lopalco L, Bini D, Delfino L, Ferrara GB, et al: HLA-C heavy chains free of beta2-microglobulin: distribution in normal tissues and neoplastic lesions of non-lymphoid origin and interferon-gamma responsiveness. Tissue Antigens 1997, 50:555-566.

13. King A, Burrows TD, Hiby SE, Bowen JM, Joseph S, Verma S, Lim PB, Gardner $L$, Le Bouteiller P, Ziegler A, et al: Surface expression of HLA-C antigen by human extravillous trophoblast. Placenta 2000, 21:376-387.

14. Schaefer MR, Williams M, Kulpa DA, Blakely PK, Yaffee AQ, Collins KL: A novel trafficking signal within the HLA-C cytoplasmic tail allows regulated expression upon differentiation of macrophages. J Immunol 2008, 180:7804-7817.

15. Falk CS, Schendel DJ: HLA-C revisited. Ten years of change. Immunol Res 1997, 16:203-214.

16. Colonna M, Borsellino $G$, Falco $M$, Ferrara $G B$, Strominger JL: HLA-C is the inhibitory ligand that determines dominant resistance to lysis by NK1- and NK2-specific natural killer cells. Proc Natl Acad Sci U S A 1993, 90:12000-12004 
17. Khakoo SI, Thio CL, Martin MP, Brooks CR, Gao X, Astemborski J, Cheng J, Goedert JJ, Vlahov D, Hilgartner M, et al: HLA and NK cell inhibitory receptor genes in resolving hepatitis $C$ virus infection. Science 2004 305:872-874.

18. Rauch A, Laird R, McKinnon E, Telenti A, Furrer H, Weber R, Smillie D, Gaudieri S: Influence of inhibitory killer immunoglobulin-like receptors and their HLA-C ligands on resolving hepatitis C virus infection. Tissue Antigens 2007, 69(Suppl 1):237-240.

19. Alter G, Martin MP, Teigen N, Carr WH, Suscovich TJ, Schneidewind A, Streeck $H$, Waring M, Meier A, Brander C, et al: Differential natural killer cell-mediated inhibition of HIV-1 replication based on distinct KIR/HLA subtypes. J Exp Med 2007, 204:3027-3036.

20. Jennes W, Verheyden S, Demanet C, Adje-Toure CA, Vuylsteke B, Nkengasong JN, Kestens L: Cutting edge: resistance to HIV-1 infection among African female sex workers is associated with inhibitory KIR in the absence of their HLA ligands. J Immunol 2006, 177:6588-6592.

21. Martin MP, Gao X, Lee JH, Nelson GW, Detels R, Goedert JJ, Buchbinder S, Hoots K, Vlahov D, Trowsdale J, et al: Epistatic interaction between KIR3DS1 and HLA-B delays the progression to AIDS. Nat Genet 2002, 31:429-434.

22. Merino A, Malhotra R, Morton M, Mulenga J, Allen S, Hunter E, Tang J, Kaslow RA: Impact of a Functional KIR2DS4 Allele on Heterosexual HIV-1 Transmission among Discordant Zambian Couples. J Infect Dis 2011, 203:487-495.

23. Pelak K, Need AC, Fellay J, Shianna KV, Feng S, Urban TJ, Ge D, De Luca A, Martinez-Picado J, Wolinsky SM, et al: Copy Number Variation of KIR Genes Influences HIV-1 Control. PLOS Biol 2011, 9:e1001208.

24. Tiemessen CT, Paximadis M, Minevich G, Winchester R, Shalekoff S, Gray GE, Sherman GG, Coovadia AH, Kuhn L: Natural killer cell responses to HIV-1 peptides are associated with more activating KIR genes and HLA-C genes of the C1 allotype. J Acquir Immune Defic Syndr 2011, 57:181-189.

25. Le Gall S, Erdtmann L, Benichou S, Berlioz-Torrent C, Liu L, Benarous R, Heard JM, Schwartz O: Nef interacts with the mu subunit of clathrin adaptor complexes and reveals a cryptic sorting signal in $\mathrm{MHC} \mathrm{I}$ molecules. Immunity 1998, 8:483-495.

26. Le Gall S, Prevost MC, Heard JM, Schwartz O: Human immunodeficiency virus type I Nef independently affects virion incorporation of major histocompatibility complex class I molecules and virus infectivity. Virology 1997, 229:295-301

27. Williams M, Roeth JF, Kasper MR, Fleis RI, Przybycin CG, Collins KL: Direct binding of human immunodeficiency virus type 1 Nef to the major histocompatibility complex class I (MHC-I) cytoplasmic tail disrupts MHC-I trafficking. J Virol 2002, 76:12173-12184.

28. Schaefer MR, Wonderlich ER, Roeth JF, Leonard JA, Collins KL: HIV-1 Nef targets MHC-I and CD4 for degradation via a final common beta-COPdependent pathway in T cells. PLoS Pathog 2008, 4:e1000131.

29. Leonard JA, Filzen T, Carter CC, Schaefer M, Collins KL: HIV-1 Nef disrupts intracellular trafficking of MHC-I, CD4, CD8, and CD28 by distinct pathways that share common elements. J Virol 2011, 85:6867-6881.

30. Cohen GB, Gandhi RT, Davis DM, Mandelboim O, Chen BK, Strominger JL, Baltimore D: The selective downregulation of class I major histocompatibility complex proteins by HIV-1 protects HIV-infected cells from NK cells. Immunity 1999, 10:661-671.

31. Collins KL, Chen BK, Kalams SA, Walker BD, Baltimore D: HIV-1 Nef protein protects infected primary cells against killing by cytotoxic $T$ lymphocytes. Nature 1998, 391:397-401.

32. Kulkarni S, Savan R, Qi Y, Gao X, Yuki Y, Bass SE, Martin MP, Hunt P, Deeks $S G$, Telenti A, et al: Differential microRNA regulation of HLA-C expression and its association with HIV control. Nature 2011, 472:495-498.

33. Goulder PJ, Edwards A, Phillips RE, McMichael AJ: Identification of a novel HLA-A24-restricted cytotoxic T-lymphocyte epitope within HIV-1 Nef. AIDS 1997, 11:1883-1884.

34. Jeannet M, Sztajzel R, Carpentier N, Hirschel B, Tiercy JM: HLA antigens are risk factors for development of AIDS. J Acquir Immune Defic Syndr 1989, 2:28-32.

35. Mann DL, Murray C, Yarchoan R, Blattner WA, Goedert JJ: HLA antigen frequencies in HIV-1 seropositive disease-free individuals and patients with AIDS. J Acquir Immune Defic Syndr 1988, 1:13-17.

36. Rohowsky-Kochan C, Skurnick J, Molinaro D, Louria D: HLA antigens associated with susceptibility/resistance to HIV-1 infection. Hum Immunol $1998,59: 802-815$.
37. Carrington M, Nelson GW, Martin MP, Kissner T, Vlahov D, Goedert JJ, Kaslow R, Buchbinder S, Hoots K, O' Brien SJ: HLA and HIV-1: heterozygote advantage and $B^{*} 35-C W^{*} 04$ disadvantage. Science 1999, 283:1748-1752.

38. Gao X, Nelson GW, Karacki P, Martin MP, Phair J, Kaslow R, Goedert JJ, Buchbinder S, Hoots K, Vlahov D, et al: Effect of a single amino acid change in MHC class I molecules on the rate of progression to AIDS. $N$ Engl J Med 2001, 344:1668-1675.

39. Altfeld M, Addo MM, Rosenberg ES, Hecht FM, Lee PK, Vogel M, Yu XG, Draenert R, Johnston MN, Strick D, et al: Influence of HLA-B57 on clinical presentation and viral control during acute HIV-1 infection. AIDS 2003, 17:2581-2591.

40. Costello C, Tang J, Rivers C, Karita E, Meizen-Derr J, Allen S, Kaslow RA: HLAB*5703 independently associated with slower HIV-1 disease progression in Rwandan women. AIDS 1999, 13:1990-1991.

41. Goulder PJ, Phillips RE, Colbert RA, McAdam S, Ogg G, Nowak MA, Giangrande $P$, Luzzi G, Morgan B, Edwards A, et al: Late escape from an immunodominant cytotoxic T-lymphocyte response associated with progression to AIDS. Nat Med 1997, 3:212-217.

42. Goulder PJ, Watkins DI: Impact of MHC class I diversity on immune control of immunodeficiency virus replication. Nat Rev Immunol 2008, 8:619-630.

43. Kiepiela P, Leslie AJ, Honeyborne I, Ramduth D, Thobakgale C, Chetty S, Rathnavalu P, Moore C, Pfafferott KJ, Hilton L, et al: Dominant influence of HLA-B in mediating the potential co-evolution of HIV and HLA. Nature 2004, 432:769-775.

44. Lazaryan A, Lobashevsky E, Mulenga J, Karita E, Allen S, Tang J, Kaslow RA: Human leukocyte antigen B58 supertype and human immunodeficiency virus type 1 infection in native Africans. J Virol 2006, 80:6056-6060.

45. Leslie A, Matthews PC, Listgarten J, Carlson JM, Kadie C, Ndung'u T, Brander C, Coovadia H, Walker BD, Heckerman D, Goulder PJ: Additive contribution of HLA class I alleles in the immune control of HIV-1 infection. J Virol 2010, 84:9879-9888.

46. Migueles SA, Sabbaghian MS, Shupert WL, Bettinotti MP, Marincola FM, Martino L, Hallahan CW, Selig SM, Schwartz D, Sullivan J, Connors M: HLA $B * 5701$ is highly associated with restriction of virus replication in a subgroup of HIV-infected long term nonprogressors. Proc Natl Acad Sci U S A 2000, 97:2709-2714.

47. O' Brien SJ, Gao X, Carrington M: HLA and AIDS: a cautionary tale. Trends Mol Med 2001, 7:379-381

48. Salgado M, Simon A, Sanz-Minquela B, Rallon NI, Lopez M, Vicario JL, Benito JM, Rodes B: An Additive Effect of Protective Host Genetic Factors Correlates With HIV Nonprogression Status. J Acquir Immune Defic Syndr 2011, 56:300-305.

49. Fitzgerald DW, Janes $H$, Robertson $M$, Coombs $R$, Frank I, Gilbert $P$, Loufty $M$, Mehrotra D, Duerr A: An Ad5-Vectored HIV-1 Vaccine Elicits Cell-mediated Immunity but does not Affect Disease Progression in HIV-1-infected Male Subjects: Results From a Randomized Placebo-Controlled Trial (The Step Study). J Infect Dis 2011, 203:765-772.

50. Migueles SA, Rood JE, Berkley AM, Guo T, Mendoza D, Patamawenu A, Hallahan CW, Cogliano NA, Frahm N, Duerr A, et al: Trivalent Adenovirus Type 5 HIV Recombinant Vaccine Primes for Modest Cytotoxic Capacity That Is Greatest in Humans with Protective HLA Class I Alleles. PLOS Pathog 2011, 7:e1002002

51. Dong $T$, Zhang $Y, X u$ KY, Yan H, James I, Peng Y, Blais ME, Gaudieri S, Chen $X$, Lun W, et al: Extensive HLA-driven viral diversity following a narrowsource HIV-1 outbreak in rural China. Blood 2011, 118:98-106.

52. McMichael AJ, Jones EY: Genetics. First-class control of HIV-1. Science 2010, 330:1488-1490.

53. Singh KK, Gray PK, Wang Y, Fenton $T$, Trout $R$, Spector SA: HLA Alleles are Associated with Altered Risk for Disease Progression and Central Nervous System Impairment of HIV-Infected Children. J Acquir Immune Defic Syndr 2011, 57:32-39.

54. Honda K, Zheng N, Murakoshi H, Hashimoto M, Sakai K, Borghan MA, Chikata T, Koyanagi M, Tamura Y, Gatanaga H, et al: Selection of escape mutant by HLA-C-restricted HIV-1 Pol-specific cytotoxic T lymphocytes carrying strong ability to suppress HIV-1 replication. Eur J Immunol 2011, 41:97-106.

55. Carrington M, Martin MP, van Bergen J: KIR-HLA intercourse in HIV disease. Trends Microbiol 2008, 16:620-627

56. Fellay J, Shianna KV, Telenti A, Goldstein DB: Host genetics and HIV-1: the final phase? PLoS Pathog 2010, 6:e1001033. 
57. Fellay J, Shianna KV, Ge D, Colombo S, Ledergerber B, Weale M, Zhang K, Gumbs C, Castagna A, Cossarizza A, et al: A whole-genome association study of major determinants for host control of HIV-1. Science 2007, 317:944-947.

58. de Bakker PI, McVean G, Sabeti PC, Miretti MM, Green T, Marchini J, Ke X, Monsuur AJ, Whittaker P, Delgado $M$, et al: A high-resolution HLA and SNP haplotype map for disease association studies in the extended human MHC. Nat Genet 2006, 38:1166-1172.

59. Study TIHC: The major genetic determinants of HIV-1 control affect HLA class I peptide presentation. Science 2010, 330:1551-1557.

60. Corrah TW, Goonetilleke N, Kopycinski J, Deeks SG, Cohen MS, Borrow P, McMichael A, Brackenridge S: Reappraisal of the relationship between the HIV-1-protective single-nucleotide polymorphism 35 kilobases upstream of the HLA-C gene and surface HLA-C expression. J Virol 2011, 85:3367-3374

61. Specht A, Telenti A, Martinez R, Fellay J, Bailes E, Evans DT, Carrington M, Hahn BH, Goldstein DB, Kirchhoff F: Counteraction of HLA-C-mediated immune control of HIV-1 by Nef. J Virol 2010, 84:7300-7311.

62. O' Huigin C, Kulkarni S, Xu Y, Deng Z, Kidd J, Kidd K, Gao X, Carrington M: The Molecular Origin and Consequences of Escape from miRNA Regulation by HLA-C Alleles. Am J Hum Genet 2011, 89:424-431.

63. Adnan S, Balamurugan A, Trocha A, Bennett MS, Ng HL, Ali A, Brander C, Yang OO: Nef interference with HIV-1-specific CTL antiviral activity is epitope specific. Blood 2006, 108:3414-3419.

64. Buseyne F, Stevanovic S, Rammensee HG, Riviere Y: Characterization of an HIV-1 p24gag epitope recognized by a CD8+ cytotoxic T-cell clone. Immunol Lett 1997, 55:145-149.

65. Johnson RP, Trocha A, Buchanan TM, Walker BD: Recognition of a highly conserved region of human immunodeficiency virus type $1 \mathrm{gp} 120$ by an HLA-Cw4-restricted cytotoxic T-lymphocyte clone. J Virol 1993, 67:438-445.

66. Littaua RA, Oldstone MB, Takeda A, Debouck C, Wong JT, Tuazon CU, Moss B, Kievits F, Ennis FA: An HLA-C-restricted CD8+ cytotoxic T-lymphocyte clone recognizes a highly conserved epitope on human immunodeficiency virus type $1 \mathrm{gag}$. J Virol 1991, 65:4051-4056.

67. Makadzange AT, Gillespie G, Dong T, Kiama P, Bwayo J, Kimani J, Plummer F, Easterbrook P, Rowland-Jones SL: Characterization of an HLA-C-restricted CTL response in chronic HIV infection. Eur J Immunol 2010, 40:1036-1041.

68. Rousseau CM, Daniels MG, Carlson JM, Kadie C, Crawford H, Prendergast A, Matthews P, Payne R, Rolland M, Raugi DN, et al: HLA class I-driven evolution of human immunodeficiency virus type 1 subtype c proteome: immune escape and viral load. J Virol 2008, 82:6434-6446.

69. Buranapraditkun $S$, Hempel U, Pitakpolrat P, Allgaier RL, Thantivorasit $P$, Lorenzen SI, Sirivichayakul S, Hildebrand WH, Altfeld M, Brander C, et al: A Novel Immunodominant CD8+ T Cell Response Restricted by a Common HLA-C Allele Targets a Conserved Region of Gag HIV-1 Clade CRF01_AE Infected Thais. PLoS One 2011, 6:e23603.

70. Nehete PN, Lewis DE, Tang DN, Pollack MS, Sastry KJ: Presence of HLA-C-restricted cytotoxic T-lymphocyte responses in long-term nonprogressors infected with human immunodeficiency virus. Viral Immunol 1998, 11:119-129.

71. Wagtmann N, Rajagopalan S, Winter CC, Peruzzi M, Long EO: Killer cell inhibitory receptors specific for HLA-C and HLA-B identified by direct binding and by functional transfer. Immunity 1995, 3:801-809.

72. Colonna M, Samaridis J: Cloning of immunoglobulin-superfamily members associated with HLA-C and HLA-B recognition by human natural killer cells. Science 1995, 268:405-408.

73. Carter AM: Comparative studies of placentation and immunology in nonhuman primates suggest a scenario for the evolution of deep trophoblast invasion and an explanation for human pregnancy disorders. Reproduction 2011, 141:391-396.

74. Biassoni R, Cantoni C, Falco M, Verdiani S, Bottino C, Vitale M, Conte R, Poggi A, Moretta A, Moretta L: The human leukocyte antigen (HLA)-C-specific "activatory" or "inhibitory" natural killer cell receptors display highly homologous extracellular domains but differ in their transmembrane and intracytoplasmic portions. J Exp Med 1996, 183:645-650.

75. Biassoni R, Falco M, Cambiaggi A, Costa P, Verdiani S, Pende D, Conte R, Di Donato C, Parham P, Moretta L: Amino acid substitutions can influence the natural killer (NK)-mediated recognition of HLA-C molecules. Role of serine-77 and lysine-80 in the target cell protection from lysis mediated by "group 2" or "group 1" NK clones. J Exp Med 1995, 182:605-609.
76. Moretta A, Vitale M, Bottino C, Orengo AM, Morelli L, Augugliaro R, Barbaresi $M$, Ciccone E, Moretta L: P58 molecules as putative receptors for major histocompatibility complex (MHC) class I molecules in human natural killer (NK) cells. Anti-p58 antibodies reconstitute lysis of MHC class I-protected cells in NK clones displaying different specificities. J Exp Med 1993, 178:597-604.

77. Alter G, Heckerman D, Schneidewind A, Fadda L, Kadie CM, Carlson JM, Oniangue-Ndza C, Martin M, Li B, Khakoo SI, et al: HIV-1 adaptation to NK-cell-mediated immune pressure. Nature 2011, 476:96-100.

78. van Bergen J, Koning F: The tortoise and the hare: slowly evolving T-cell responses take hastily evolving KIR. Immunology 2010, 131:301-309.

79. Alter G, Rihn S, Streeck H, Teigen N, Piechocka-Trocha A, Moss K, Cohen K, Meier A, Pereyra F, Walker B, Altfeld M: Ligand-independent exhaustion of killer immunoglobulin-like receptor-positive CD8+ T cells in human immunodeficiency virus type 1 infection. J Virol 2008, 82:9668-9677.

80. Esser MT, Graham DR, Coren LV, Trubey CM, Bess JW Jr, Arthur LO, Ott DE, Lifson JD: Differential incorporation of CD45, CD80 (B7-1), CD86 (B7-2), and major histocompatibility complex class I and II molecules into human immunodeficiency virus type 1 virions and microvesicles: implications for viral pathogenesis and immune regulation. J Virol 2001, 75:6173-6182

81. Hunsmann G, Dormont D, Le Grand R, Cranage M, Greenaway P, Stahl-Hennig C, Rossi G, Verani P, Stott J, Kitchin P, et al: Protection of macaques against simian immunodeficiency virus infection with inactivated vaccines: comparison of adjuvants, doses and challenge viruses. The European Concerted Action on' Macaque Models for AIDS Research'. Vaccine 1995, 13:295-300.

82. Ott DE: Cellular proteins in HIV virions. Rev Med Virol 1997, 7:167-180.

83. Putkonen $\mathrm{P}$, Thorstensson R, Cranage M, Nilsson C, Ghavamzadeh L, Albert J, Greenaway P, Biberfeld G: A formalin inactivated whole SIVmac vaccine in Ribi adjuvant protects against homologous and heterologous SIV challenge. J Med Primatol 1992, 21:108-112.

84. Stott EJ: Anti-cell antibody in macaques. Nature 1991, 353:393.

85. Tremblay MJ, Fortin JF, Cantin R: The acquisition of host-encoded proteins by nascent HIV-1. Immunol Today 1998, 19:346-351.

86. Lakhashe SK, Thakar MR, Bharucha KE, Paranjape RS: Quantitation of HLA proteins incorporated by human immunodeficiency virus type 1 and assessment of neutralizing activity of anti-HLA antibodies. J Virol 2008 82:428-434.

87. Arthur LO, Bess JW Jr, Sowder RC 2nd, Benveniste RE, Mann DL, Chermann $J C$, Henderson LE: Cellular proteins bound to immunodeficiency viruses: implications for pathogenesis and vaccines. Science 1992, 258:1935-1938.

88. Zhu P, Liu J, Bess J Jr, Chertova E, Lifson JD, Grise H, Ofek GA, Taylor KA, Roux $\mathrm{KH}$ : Distribution and three-dimensional structure of AIDS virus envelope spikes. Nature 2006, 441:847-852.

89. Cantin R, Fortin JF, Lamontagne G, Tremblay M: The presence of host-derived HLA-DR1 on human immunodeficiency virus type 1 increases viral infectivity. J Virol 1997, 71:1922-1930.

90. Cantin R, Fortin JF, Lamontagne G, Tremblay M: The acquisition of host-derived major histocompatibility complex class II glycoproteins by human immunodeficiency virus type 1 accelerates the process of virus entry and infection in human T-lymphoid cells. Blood 1997, 90:1091-1100.

91. de Santis C, Robbioni P, Longhi R, Carrow E, Siccardi AG, Beretta A: Role of HLA class I in HIV type 1-induced syncytium formation. AIDS Res Hum Retroviruses 1996, 12:1031-1040.

92. Cosma A, Blanc D, Braun J, Quillent C, Barassi C, Moog C, Klasen S, Spire B, Scarlatti G, Pesenti E, et al: Enhanced HIV infectivity and changes in GP120 conformation associated with viral incorporation of human leucocyte antigen class I molecules. AIDS 1999, 13:2033-2042.

93. Matucci A, Rossolillo P, Baroni M, Siccardi AG, Beretta A, Zipeto D: HLA-C increases HIV-1 infectivity and is associated with gp120. Retrovirology 2008, 5:68.

94. Beretta A, Grassi F, Pelagi M, Clivio A, Parravicini C, Giovinazzo G, Andronico F, Lopalco L, Verani P, Butto S, et al: HIV env glycoprotein shares a cross-reacting epitope with a surface protein present on activated human monocytes and involved in antigen presentation. Eur J Immunol 1987, 17:1793-1798.

95. Grassi F, Meneveri R, Gullberg M, Lopalco L, Rossi GB, Lanza P, De Santis C, Brattsand G, Butto $S$, Ginelli $E$, et al: Human immunodeficiency virus type 1 gp120 mimics a hidden monomorphic epitope borne by class I major histocompatibility complex heavy chains. J Exp Med 1991, 174:53-62. 
96. Fan $\mathrm{QR}$, Wiley DC: Structure of human histocompatibility leukocyte antigen (HLA)-Cw4, a ligand for the KIR2D natural killer cell inhibitory receptor. J Exp Med 1999, 190:113-123.

97. Finzi A, Brunet A, Xiao Y, Thibodeau J, Cohen EA: Major histocompatibility complex class II molecules promote human immunodeficiency virus type 1 assembly and budding to late endosomal/multivesicular body compartments. J Virol 2006, 80:9789-9797.

98. Gottlinger HG: The HIV-1 assembly machine. AIDS 2001, 15(Suppl 5):S13-S20

99. MacAry PA, Lindsay M, Scott MA, Craig Jl, Luzio JP, Lehner PJ: Mobilization of MHC class I molecules from late endosomes to the cell surface following activation of CD34-derived human Langerhans cells. Proc Natl Acad Sci U S A 2001, 98:3982-3987.

100. Arosa FA, Santos SG, Powis SJ: Open conformers: the hidden face of MHC-I molecules. Trends Immunol 2007, 28:115-123.

101. Martayan A, Fraioli R, Giorda E, Setini A, Ciccarelli G, Delfino L, Ferrara GB, Giacomini P: Biosynthesis of HLA-C heavy chains in melanoma cells with multiple defects in the expression of HLA- $\mathrm{A},-\mathrm{B},-\mathrm{C}$ molecules. $\mathrm{Br} J$ Cancer 1999, 80:639-649.

102. Mothe B, Llano A, Ibarrondo J, Zamarreno J, Schiaulini M, Miranda C, Ruiz-Riol $M$, Berger CT, Herrero MJ, Palou E, et al: CTL Responses of High Functional Avidity and Broad Variant Cross-Reactivity Are Associated with HIV Control. PLoS One 2012, 7:e29717.

doi:10.1186/1742-4690-9-39

Cite this article as: Zipeto and Beretta: HLA-C and HIV-1: friends or foes? Retrovirology 2012 9:39.

\section{Submit your next manuscript to BioMed Central and take full advantage of:}

- Convenient online submission

- Thorough peer review

- No space constraints or color figure charges

- Immediate publication on acceptance

- Inclusion in PubMed, CAS, Scopus and Google Scholar

- Research which is freely available for redistribution 